\title{
Geographical Work of the Geological Survey of Canada in 1895
}

\section{Author(s): George M. Dawson}

Source: The Geographical Journal, Vol. 7, No. 4 (Apr., 1896), pp. 412-414

Published by: geographicalj

Stable URL: http://www.jstor.org/stable/1773553

Accessed: 18-05-2016 06:20 UTC

\section{Your use of the JSTOR archive indicates your acceptance of the Terms \& Conditions of Use, available at}

http://about.jstor.org/terms

JSTOR is a not-for-profit service that helps scholars, researchers, and students discover, use, and build upon a wide range of content in a trusted digital archive. We use information technology and tools to increase productivity and facilitate new forms of scholarship. For more information about JSTOR, please contact support@jstor.org.

The Royal Geographical Society (with the Institute of British Geographers), Wiley are collaborating with JSTOR to digitize, preserve and extend access to The Geographical Journal 
Since the occupation of Ulu by the Company, Kitwyi has been the principal rendezvous for slave-traders in this part of the territory. Our late expedition there, and the furtunate capture of some Swahili slave-traders red-handed in their business, will, I feel sure, have a good effect in Kitwyi; but, in my opinion, it is urgently necessary that the country be occupied, and be administered by nearer means than Machako's. There is, I understand, a lot of traffic in ivory and slaves through Nengia (Kitwyi), and of these caravans some pass down the Sabaki to Takaungu, while others strike right across German territory, and eventually make Pangani. Independent of the above-mentioned traffic, there is a very fair trade in cattle, etc., in the country, and many Swahilis are at times semi-resident in the country; many Wagiriama traders also come into this country and Mumoni to buy cattle and ivory, and at times many Kitwyi people go down to Giriama and Mombasa to trade.

Another important matter is as follows. In Meranga there are a great many unfortunate Masai women slaves of the Wakikuyu. Many of the Swahili traders coming through Meranga from Baringo, Kavirondo, etc., buy a lot of thess women cheap; the Swahilis then come to Kitwyni, where they sell some of these women for cattle. They then send a party to Mumoni with their cattle to buy ivory. I understand that the Kitwyi people will not undertake the risk of taking cattle to Kikuyu to buy women, while, on the other hand, the Wakikuyu will not risk bringing the women into Kitwyi, and so the Swahili is the middleman. To control all this it is very necessary that a European officer should be resident in the country.

Personally I am very well pleased with the result of my visit. I found the people very friendly, and very anxious that a European should come and reside amongst them. On my return several young fellows accompanied us to Machako's, mainly to see the station, etc.

\section{GEOGRAPHICAL WORK OF THE GEOLOGICAL SURVEY OF CANADA IN 1895.}

By Dr. GEORGE M. DAWSON, C.M.G., F.R.S.

The work of the Geological Survey of Canada in 1895 has been largely devoted to the systematic mapping of definite areas, and did not include nearly as much geographical exploration as that of the preceding year.

In British Columbia, Mr. R. G. McConnell and Mr. J. McEvoy were engaged respectively upon the West Kootanie and Shuswap sheets of the geological map, the geographical and topographical delineation of the country proceeding in both cases concurrently with its geological examination. A great developm ${ }^{\wedge}$ t of mining is in progress in British 
Columbia, more particularly of the precious metals, and the West Kootanie district is now occupied by a large mining population, although a few years ago it was practically an untrodden wilderness.

To the east of the northern part of Lake Winnipeg, in Manitoba, Mr. J. B. Tyrrell carried out surveys of an exploratory nature, laying down the courses of several rivers and ascertaining the positions of a number of lakes, as well as the geological character of the country, which proved to be characterized entirely by granitic and gneissic rocks.

In the Rainy river and Thunder bay districts of Western Ontario, Mr. W. McInnes completed the information necessary for the Seine river and Shebandowan map-sheets, and a preliminary edition of the first-named sheet has been published, in order to meet the requirements of the miners engaged in the discovery and preliminary exploitation of auriferous quartz-veins there. The rocks met with are all referable either to the Laurentian or to the Huronian system, the latter being that containing the gold-bearing deposits. Similar conditions recur in the country adjacent to the Upper Ottawa, in the vicinity of lakes Temiscaming and Nipissing, where the greater part of the season was spent by Mr. A. Barlow. The adjacent Sudbury district is well known because of its nickeliferous pyrrhotites, and similar ores are in process of discovery in the Huronian rocks of the farther region here particularly referred to. It includes also one of the typical Huronian areas originally described by Sir William Logan, the re-examination of which, in the light of modern petrographical methods, is producing many facts of scientific interest.

Systematic surveys of both sides of the lower part of the Ottawa were also continued by Dr. R. W. Ells, and in the tract between the Ottawa and St. Lawrence by Mr. N. J. Giroux. The general geological features have here long been known, but they are now being laid down for the first time in some detail on the scale of four miles to the inch.

In the northern part of the province of Quebec, an exploration of considerable geographical and geological interest was carried out by Dr. R. Bell, who crossed the height of land from Grand lake, near the sources of the Ottawa, and descended the Nottaway or Noddawai river to its mouth on James bay. Much of the country traversed, although relatively near to inhabited centres, had not before been mapped, and it had remained uncertain whether the stream known to rise near Grand lake was part of the Nottaway system or that of a river emptying further to the west, in Hannah bay. A large area of Huronian rocks was here again met with.

Examination made in that part of Quebec to the south of the St. Lawrence by Mr. R. Chalmers, were directed chiefly to the alluvial gold deposits and to the facts of the glacial period which bear directly 
upon these. Terraces marking late-glacial sea-margins were measured to a maximum certain height of 885 feet, and evidence appears to be accumulating to show that these represent the "Iroquois beach," or terrace, of the region of the Great lakes, and these must in that case have been at the time in direct connection with the sea, forming an extensive inlet.

To the north of the Gulf of St. Lawrence, Mr. A. P. Low continued his explorations of the Labrador peninsula by ascending to the sources of the Manikugan river, and examining a tract of country on both sides of the main watershed about its sources. Granites, with Laurentian gneisses and limestones, and intrusive masses of anorthosite, characterize the whole region traversed.

In Nova Scotia, Mr. H. Fletcher was employed in revising the maps of the Sydney coal-field of Cape Breton, preparatory to the issue of a new edition of these; and $\mathrm{Mr}$ E. R. Faribault continued his detailed mapping of the Cambrian gold-bearing rocks of the Atlantic coast, for publication on the sale of a mile to the inch. The auriferous quartzveins are here intimately connected with the anticlinal axes, which it is therefore necessary to trace out with all practicable precision.

In the absence of any trustworthy, detailed, and connected topographical surveys, all the work above outlined has implied measurements and traverses of country adding materially to geography. It is impossible, under the circumstances, to employ methods of great precision, the means adopted being in each case commensurate merely with the requirements of the scale adopted, but the resulting maps are always far in advance of any previously existing.

During the year 1895 twenty-six maps in all have been issued by the Geological Survey.

\section{GENERAL CHAPMAN'S PROPOSED MAPPING OF AFRICA.}

Mr. J. Temple Horne, the surveyor-general of Cape Colony, has issued a report dealing with General Chapman's proposals, and directs attention to the important geodetic surveys which have been carried out in South Africa since 1840. A complete series of primary triangles already connects Cape Town with the country near the lower Orange river and with Natal. In British Bechuanaland surveying operations were begun in 1886, when Lieut. Laffan measured a base-line near the Hart river, and a series of primary triangles has now been carried from the twentieth meridian to the boundary of the South African Republic. The work still to be done to render this colonial network of primary triangles complete includes the measurement of three additional chains of triangles, namely, one across the Orange Free State, joining Natal to Kimberley; a second to join Kimberley to the eastern part of the 